\title{
Abortion and same-sex marriage: how are non-sectarian controversial issues discussed in Northern Irish politics?
}

Westminster's legislation regarding marriage rights for same sex couples has not be extended to Northern Ireland. Similarly, Northern Ireland has never been under the jurisdiction of the 1967 Abortion Act, making abortion effectively illegal in the province unless it is necessary to preserve the long-term life or health of the woman. This article considers contemporary political debate around abortion and same-sex marriage in Northern Ireland to ask; how are controversial (but non-sectarian) issues such as abortion and same sex marriage dealt with in a divided society? Using data from the Northern Ireland Life and Times Survey and selected debates from the Northern Irish Assembly, it considers how political parties and post-conflict governance have shaped debate on these issues.

Keywords: Northern Ireland, gender, abortion, same-sex marriage 
Abortion and same-sex marriage: how are non-sectarian controversial issues discussed in Northern Irish politics?

Falling outside of the dominant conception of post-conflict identity as primarily ethnonational, cross-cutting issues around sexuality and gender in divided societies such as Northern Ireland and Bosnia-Herzegovina have had less attention within academic literature. Consideration of ethno-national identity has been dominant, and has come at the expense of understanding other types of social difference. In work on post-conflict governance and policy-making, non-ethno-national issues are largely left to one side (for example Noel, 2005); equally, in literature on gender or sexuality politics, divided societies are deemed a 'special' case, or overly specific due to their complex politics, and not included in discussion (Larsen et al, 2012, Sheldon, 1997).

Outside of this mainstream literature, feminist and gender scholars have done much to emphasise these absences. Political theory has highlighted the extent to which (ethno)nationalist sentiment is underpinned by gendered conceptions of the nation (Parker et al, 1992, Yuval-Davis, 1997). Research has brought to light the ways in which women were often active participants in ethno-national struggles, and used their involvement to further develop feminist agendas (O'Keefe, 2013). The role of gender in peacekeeping and reconstruction has been highlighted (McLeod, 2011, Shepherd, 2008), as has the (re)entrenchment of traditional gender roles in post-conflict situations (Cockburn and Zarkov, 2002, Enloe, 1993).

This literature has tended to look at gender from a macro level, considering it as a structural force at the level of the state or peacebuilding operations, or a conceptual framework for the national community. Less attention has thus been paid to specific gendered policy issues in the post-conflict setting, and how these issues have influenced party politics or the work of new political institutions. This article seeks to address this gap by looking at two particular policy areas in post-conflict Northern Ireland: abortion and same-sex marriage. As Htun (2003) reminds us, gender issues cannot be treated homogenously: "differences among gender issues are politically consequential" and must be "disaggregated" rather than treated as a "single issue area" (1-2). Doing so here allows for a broader picture of how gender issues are discussed in a new political institution, and how they may create new inter-party tensions or alliances in the post-conflict setting.

In Northern Ireland especially, "mainstream conflict transformation scholarship ... has failed to provide a research base for sexual politics" (Ashe, 2009, 25). The small amount of literature produced on LGBT politics in the province has largely worked from a social movements perspective, from within the discipline of Anthropology, (Curtis, 2013, Nagle, 2012) or employing life history interviews to gain a broad picture of the lesbian and gay community in Northern Ireland (Duggan, 2012). There has been little understanding of how contemporary political discourse or the specific political structures created in devolved Northern Ireland might affect discussion and debate around LGBT issues. Similarly, consideration of women-specific policy issues in Northern Irish politics is limited. Whilst the descriptive representation of women in formal Northern Irish politics has been well documented (Cowell-Meyers, 2001, Fearon, 1999, Galligan et al, 1999, Matthews, 2014, Tonge et al, 2014, Ward, 2002), there has been less consideration of substantive political issues. The little literature produced on abortion specifically has focused more on sociological aspects (Smyth, 2006), and on the potential for liberalisation inherent in legal reform (Bloomer and Fegan, 2013, Fegan and Rebouche, 2003, Horgan and O'Connor, 2014). The political aspects of abortion, both in terms of party policies and the issue's salience in contemporary political structures, have been neglected. 
Mainstream literature on Northern Irish politics has thus little considered specific gendered policy issues, but has also under-theorised how these issues impact and shape political discourse. This article will consider contemporary political debate around abortion and samesex marriage in Northern Ireland to ask; how does a formal political structure which is still deeply divided along ethno-national lines deal with non-sectarian controversial issues? How are abortion and same sex marriage addressed in the institutional framework of the 'new' Northern Irish politics (Tonge, 2005)?

\section{Case selection and data}

As Northern Ireland has grown more peaceful, and as vivid symbols of the end of conflict have occurred (the St Andrew's agreement led to the DUP and Sinn Féin entering into government together in 2007; Deputy First Minister and former Provisional IRA member Martin McGuinness formally met the Queen and shook her hand in 2012), socio-cultural issues have become a new terrain of political contestation. Whilst politics and social relations continue to normalise in many areas of the province, new divisions (and new alliances) are being formed in regards to policy areas that had little consideration during the Troubles. The role of what have been termed the developing 'culture wars' in Northern Irish politics and society has had little academic consideration. Mycock and McDaid argue (2014) that the 'culture wars' in the province have two distinct strands. The first is related to the public display of national beliefs and identity: the flying of flags in public space, the Irish language act and the parading activities of both the Orange Order and various Republican groups. This strand has distinct green-orange ${ }^{i}$ tendencies, redolent of traditional sectarian leanings, and largely follows nationalist-unionist party and voting lines. The Irish Language Act, for example, for which proposed legislation emerged in early 2015 , has been strongly promoted by nationalist Sinn Féin and equally strongly attacked by unionist parties, most especially the Democratic Unionist Party (the DUP) and Traditional Unionist Voice (the TUV).

For Mycock and McDaid, the second strand of the 'culture wars' is concerned with social and moral issues (abortion, same sex marriage, blood donation by men who have sex with men, accommodation of ethnic/racial minorities etc.) and is less aligned to green or orange leanings or political parties. In general, Northern Ireland remains far more socially conservative than the rest of the United Kingdom. Neither the 1967 Abortion Act nor the 2013 Marriage (Same Sex Couples) Act apply in the province. As such, abortion remains illegal where there is a long term risk to the woman's physical or mental health. Civil partnerships are legal but only largely because they were enacted in 2004 from Westminster when direct rule was still in force. Successive Health Ministers have now upheld a ban on men who have sex with men donating blood (this policy was changed in the rest of the UK in 2011, where men who have not been sexually active for one year may donate blood), and the province has seen a series of widely-publicised racial attacks in recent years. Socially conservative attitudes around some of these issues, particularly with regards to abortion, cut across ethno-national and party political divisions (Horgan and O'Connor, 2014). Whilst issues around clear-cut topics of nationality, such as flags and language, are clearly divided along nationalist-unionist lines, socio-cultural issues such as those described here are not so easily categorised.

Both abortion and same sex marriage have received especial consideration in Northern Ireland in a contemporary setting. Since the opening of a Marie Stopes Clinic in central Belfast in late 2012, abortion has received much political discussion. In late 2013 the case of a woman with a pregnancy with fatal foetal abnormality received much media attention. ${ }^{\text {ii }}$ The Justice Minister is now seeking a change in the law to allow for termination in the province in 
such circumstances. In England and Wales same sex marriage was legalised in 2013, and in Scotland in 2014. Northern Ireland's difference in this regard has prompted renewed political debate around the issue.

The growth in the political prescience of these issues has occurred against a backdrop in which Northern Irish politics has changed dramatically. The Northern Irish Assembly, established by the Good Friday Agreement of 1998, saw the Ulster Unionist Party (the UUP) and the Social Democratic and Labour Party (the SDLP) dominate their pool of respective ethno-national voters (Protestant unionists and Catholic nationalists respectively). Almost immediately following devolution votes began to shift from the UUP to the Democratic Unionist Party (the DUP) and from the SDLP to Sinn Féin. Sinn Féin and the DUP now overwhelmingly dominate the Assembly, with the DUP now the largest party. Despite suggestions that this may illustrate a slide to the 'extremes' for formal politics, rather than moderation (Collier, 2010, 57), previous work suggests that voting changes do not represent "increased overall polarisations" (Mitchell et al, 2008, 417) in the views of the electorate. Regardless, both parties draw their votes from two very different communities, with little convergence in voters (Evans and Tonge, 2009), or views on the constitutional question.

<Tables 1 and 2 about here>

Party policy on these issues differs widely. The DUP is strongly socially conservative (Tonge et al, 2014). Key senior members have made clear their conservative stance on same-sex marriage. Former Health Minister, Jim Wells DUP MLA, is on record as stating his opposition to abortion even in cases of rape. ${ }^{\text {iii }}$ Whilst Sinn Féin are more liberal on LGBT issues, their position on abortion - that they are "opposed to the attitudes and forces in society, which pressurise women to have abortions, and criminalise those who make this decision"iv - is vague. The SDLP are vocally supportive on the issue of LGBT rights but largely opposed to abortion. Both the UUP and the Alliance party treat abortion as an issue of conscience, and do not whip votes on the topic. These issues are also generally absent from party literature or manifesto. In light of a range of vaguely expressed policy positions, or treatment of these issues as matters of conscience for individual MLAs, the recent debates in the Northern Irish Assembly are thus the most important place to turn to in order to gain an understanding of how parties and individual members understood these issues.

In March 2012 and April and October of 2013 the issues of abortion and same-sex marriage were subject to debate in the Northern Irish Assembly. Amendments proposed regarding both were stopped due to use of the petition of concern. The petition is a particular feature of the devolved institution, designed to allow for minority dissent (O'Leary, 2004, 290), but which can be employed on any topic as long as there is sufficient support within the Assembly. A petition requires the signature of 30 of the 108 MLAs (Member of the Legislative Assembly), and any vote on which the petition of concern is expressing disquiet cannot be held until a day after it is registered. The ensuing vote then needs $60 \%$ of the legislature to approve it, including $40 \%$ from both the Nationalist and Unionist sides. ${ }^{\mathrm{v}}$

In what follows, abortion and same sex marriage will be considered separately. Firstly, a brief historical context will be provided for both issues given that their legal treatment often differs quite starkly from the broader United Kingdom. Secondly, using data from the Northern Ireland Life and Times Survey, the cross-cutting opinions on abortion and same sex marriage, and their relatively non-communal nature will be illustrated. Thirdly, the discourse of the debates in the Assembly will be analysed in order to gain a greater appreciation of how these 
Abortion and same-sex marriage: how are non-sectarian controversial issues discussed in Northern Irish politics?

issues are approached and what, if any, party or communal lines and attitudes exist towards these issues.

\section{Abortion in Northern Ireland}

Abortion was first addressed in legislation in Great Britain in the 1861 Offences Against the Person Act. This made any attempt to procure a miscarriage, or supply of drugs or other material aid to procure a miscarriage, punishable by life imprisonment. This legislation was largely untouched until 1929, when the Infant Life (Preservation) Act prohibited the destruction of a child 'capable of being born alive'. In 1937 a prominent London surgeon, Alec Bourne, openly performed an abortion on a 14 year old girl who was pregnant as the result of rape by a group of soldiers. Until the 1967 Abortion Act, R. vs. Bourne was the only addition to abortion legislation, and still largely forms the basis of what constitutes a legal abortion in Northern Ireland today. It states that: "If the doctor is of the opinion, on reasonable grounds and with adequate knowledge that the probable consequences of the continuance of the pregnancy will be to make the woman a physical or mental wreck" (Sheldon, 1997, 79, emphasis added) then an abortion is deemed legal. The vague nature of this judgement, however, resulted in a wide variation in implementation.

In light of this ambiguity, there was growing pressure for more transparent legislation. At the behest of both the medical profession, frustrated with the uncertainty surrounding the procedure, and coupled with a media and political discourse which painted women as the poor, helpless victims of money-grabbing backstreet abortionists, public and political opinion was behind liberalisation (Sheldon, 1997). The 1967 Abortion Act allowed for abortion at up to 28 weeks with the permission of two doctors, but in a manner which continued the medicalisation of the Bourne judgement. It continues to form the legal basis upon which women access terminations today in Scotland, England and Wales. ${ }^{\text {vi }}$ Yet it was never extended to Northern Ireland, largely because the province was at that point still governed by the parliament at Stormont.

Attempts were made in 2008 to extend the law to Northern Ireland during the passage of amendments to the Human Fertilisation and Embryology Act as it moved through

Westminster. The proposed amendment was quietly pushed down the running order within parliament, due, it was conjectured at the time, to the fact that Northern Irish MPs from the DUP agreed to vote for the Labour government's proposed 42 day terror suspect detention limit in exchange for a promise that Labour would not attempt to extend the 1967 Act to Northern Ireland. ${ }^{\text {vii }} 2010$ saw further justice and policing powers devolved to the province, as a result of which change to abortion legislation can now only come from the devolved parliament at Stormont.

Contemporary public opinion on the issue suggests greater toleration for abortion in limited circumstances than the current strict legislation provides for. Since its inception, the Northern Ireland Life and Times Survey has asked the below questions on three separate occasions (1998, 2004 and 2008), and the responses have varied little. ${ }^{\text {viii }}$ The phrasing of the questions deliberately frames abortion in two separate ways: in Table 3, as a social issue, where the woman chooses not to have an abortion given her personal and familial circumstances, and in Table 4, as a medical issue. Greater public support has consistently been shown across the years for abortion when need arises from a medical, as opposed to a social, problem. Similarly, people of no religion have always shown greater acceptance of abortion for either reason presented. Those identifying as no religion have always been very much the minority. In the 2008 survey, $13 \%$ identified as having no religion, $6 \%$ as a different religion, $36 \%$ as Catholic and 55\% as some denomination of Protestant. Religion is used here, not to 
Abortion and same-sex marriage: how are non-sectarian controversial issues discussed in Northern Irish politics?

emphasise any theological stance on the issue, but as a means of understanding the political affiliations of the two communities. In spite of the use of the single transferable voting system, Protestants continue to vote overwhelmingly for Unionist parties, and Catholics for Nationalist parties (Tonge, 2005).

<Tables 3 and 4 about here>

According to these statistics, public opinion is thus not as rigid as politicians often imply (a statement such as that of Jonathan Bell MLA DUP, in the March 2013 Assembly debate on the issue, "On a cross-community basis, the women of Northern Ireland ... are very clear that they do not want the Abortion Act extended to Northern Ireland", for example, is far from uncommon. ${ }^{\text {ix }}$ ) The Northern Irish populace appear supportive of more liberal legislation which might allow for abortion in certain circumstances. Although a majority (53\%) of Catholics see abortion as 'Always wrong', 22\% view it as 'Wrong only sometimes' or 'Not wrong at all'. Protestants are more equally divided on the issue of social abortion, with $39 \%$ seeing it as 'Always wrong', but $30 \%$ viewing it as 'Wrong only sometimes' or 'Not wrong at all'. Both communities are far more acceptant of abortion for medical reasons. $35 \%$ of Catholics consider it to be 'Always wrong', and 37\% 'Wrong only sometimes' or 'Not wrong at all'. Similarly, $21 \%$ of Protestants consider medical abortion to be 'Always wrong', whilst $50 \%$ view it as 'Wrong only sometimes' or 'Not wrong at all'. These statistics illustrate that, whilst Catholics appear less acceptant than Protestants on the whole, both communities are too divided on the issue for this to be seen as a particularly Catholic or Protestant concern. Political reticence to express decisive action either through manifesto or legislation is therefore obvious. Moreover, the clear difference between abortion as a social issue and abortion as a medical issue suggests that public opinion on the whole is more nuanced than political discourse might at times suggest.

\section{Abortion Politics in the Contemporary Northern Ireland Assembly}

From late 2012 onwards, the issue of abortion returned to prominent political debate in the province. In October 2012, a Marie Stopes clinic was opened in Belfast with facilities to provide terminations for up to 9 weeks of pregnancy. Later that same month, Savita Halappanavar died of septicaemia after being denied a termination in a Galway hospital in the Republic of Ireland. Both events reignited the debate around abortion in the province.

In a direct challenge to the Marie Stopes clinic, and in a rare moment of cross-communal alliance, a motion to amend the Criminal Justice Bill was co-proposed by the DUP (Paul Givan MLA), the UUP (Tom Elliot MLA) and the SDLP (Alban Maginness MLA) in March 2012 to limit provision of termination to NHS facilities, thus effectively outlawing Marie Stopes from working in the province. A petition of concern was registered by a joint Sinn Féin (Caitríona Ruane MLA), Alliance (Anna Lo MLA) and Green (Stephen Agnew MLA) grouping, stopping the proposed legislation at the eleventh hour. ${ }^{\mathrm{x}}$ MLAs finally voted 53 to 40 against the amendment, with 9 nationalists voting for the amendment, and 5 unionists against it, showing a considerable divergence from a straight Nationalist/Unionist split. All MLAs designated as other voted against it.

The debate in the Assembly was heated, but, in spite of the use of the petition of concern, showed little communal partisan quality. Unionist members, especially from the DUP, did take the chance to attack Sinn Féin for what was perceived to be their avowedly pro-choice stance. Arlene Foster MLA, DUP, argued that the assembly was "witnessing the ideological meltdown of Sinn Féin. ... We have known for some time that Sinn Féin is morally bankrupt in everything that it has been involved in over the past 40 years. However, I know that the Member will agree with me that what we have here today is an example of its ideological 
Abortion and same-sex marriage: how are non-sectarian controversial issues discussed in Northern Irish politics?

bankruptcy."xi The notion that Sinn Féin were an immoral, pro-choice party (and to a certain extent the Alliance and Green parties also), was a recurring attack from DUP members in the debate.

Across the ethno-national political divide, members from multiple political parties took great lengths to emphasise what they perceived to be the cross-communal, and indeed, crossborder, nature of feeling around this issue: "I support the amendment proposed by the crossparty and cross-community group of Members. It reflects the widespread support for strict regulation of abortion here in the North and across the island of Ireland" (McGlone MLA, SDLP). One of the sponsors of the amendment Paul Givan MLA, DUP, also cited all-Ireland support for the present situation ("Across the island of Ireland, we share a common bond in seeking to protect and provide the best care for mothers and unborn children"), and frequently attacked those opposing the amendment given the "cross-party and crosscommunity support" it had.

As a result of this cross-community ethos, the use of the petition of concern annoyed several MLAs: "My problem is with the petition of concern. Sinn Féin, Ms Lo and Mr Agnew knew that, on a cross-community basis, a majority of MLAs in the House would vote for the protection of the unborn child. You knew that. You did the sums" (Wells MLA, DUP). Sinn Féin were quick to argue however, that it was the DUP who had misused the petition: "on a majority of occasions, the petition of concern has been used by a single party - the DUP - as a means of blocking motions in the Assembly" (Ruane MLA, Sinn Féin). Furthermore, the debate revolved around the issue of where healthcare provision should lie: "it is an issue of private healthcare versus public healthcare" (Ruane MLA, Sinn Féin). Rather than discussing abortion, and the very restricted provision allowed in Northern Ireland more specifically, the debate was part of a broader discussion on private healthcare. Regardless of its failure, the debate helped to give the DUP and the SDLP considerable pro-life credentials, and a majority Sinn Féin supported petition of concern allowed them to stand down any accusation that their party was not supportive of women's rights. Even if the motion did not pass, it still rewarded each side with a certain public perception of their party's ethos.

\section{Same-sex Marriage in Northern Ireland}

Same sex marriage, like abortion, was a key political issue in Northern Ireland between 2012 and 2013. The issue of same-sex marriage has a far shorter legislative history in the United Kingdom than does abortion. Same-sex unions were initially conceived of as Civil Partnerships in the 2004 Civil Partnership Act. This gave same sex couples the same rights and responsibilities of marriage - inheritance, next of kin rights in hospitals, pensions etc. but religious music, readings and imagery were expressly forbidden during these ceremonies. This Act was extended to Northern Ireland (largely because direct rule from Westminster was at that point enacted) but opposed by the DUP and the UUP. In 2012-2013, Prime Minister David Cameron spearheaded attempts to pass the 2013 Marriage (Same sex couples) bill. In practical terms, this will afford same sex couples very little real difference from a civil partnership, but will make ceremonies conducted in religious settings legal. As with abortion the issue of same-sex marriage is devolved to the Assembly at Stormont.

$<$ Table 5 about here>

In a similar manner to abortion, public opinion in Northern Ireland has greater complexity than political ongoings might at times suggest. Stronger public support is clearly seen from Catholic than Protestant respondents (see Table 5). As with abortion, those of no religion expressed greatest support, although over a quarter do not support it or do not know their opinion. Although Catholics are on the whole more supportive, a large minority believes 
same-sex marriage should not be valid, or are unsure. The near 50-50 Protestant split suggests a community too divided to have one cohesive view on the subject, again explaining why Stormont or individual political parties may appear reticent to act. The picture is one of ambiguity towards the issue on both sides of the community. Again, like abortion, it does not present itself as an explicitly communal topic.

\section{Same-sex Marriage Politics in Northern Ireland}

Same-sex marriage has been debated twice by the Assembly at Stormont, at points that roughly correlate to the equivalent debates going on at the same time in Westminster. In October 2012, a motion was jointly tabled by Sinn Féin and the Green Party calling on the government to ensure that "all married couples, including those of the same sex, should have the same legal entitlement to the protections, responsibilities, rights, obligations and benefits afforded by the legal institution of marriage; calls on the Minister of Finance and Personnel to introduce legislation to guarantee that couples of any sex or gender identity receive equal benefit". ${ }^{\text {ii }}$ A petition of concern was filed by the DUP. All nationalist MLAs voted for the amendment, with only three unionist MLAs joining them in doing so.

The debate, although largely split along traditional nationalist-unionist lines in terms of the final vote, followed the logic of equality versus traditional definitions of marriage. Members supportive of the amendment were keen to stress the logic of equal rights that they believed to be inherent in their argument: "This is a debate about equal rights. It is about freedom from discrimination and stigmatisation. It is about legal protections and responsibilities, and the rights, obligations and benefits afforded by the legal institution of marriage" (Bradley MLA, DUP). Opponents characterised the issue more as an unnecessary stretching of the notion of equality: "This is not a debate about equality; rather it is a debate about redefining the centuries-old meaning of the word "marriage". It is simply a myth that this is an equality issue" (Mcllveen MLA, DUP). The debate, although the voting patterns largely mirrored traditional political division, was generally conducted along a liberal-conservative understanding of the issue, rather than the issue being of direct relevance to communal politics.

Moreover, when a Member did, at one point in the debate, attempt to relate the issue to a more conventionally partisan issue, that of parading, he was quickly berated and encouraged to return to the topic at hand:

Mr Kennedy: It is interesting that the Member referred to her participation and that of her party in the Gay Pride parade in Newry on Saturday. It seemed to strike a different chord when it approached the right of others to assemble peacefully to celebrate the Ulster covenant in Belfast. [Interruption.]

Mr Speaker: Order.

Ms Ruane: First of all, I will not allow the Member to hide behind other issues. Let us have a debate - [Interruption.]

Mr Speaker: Order.

Ms Ruane: Let us have a debate on those other issues, and I will be the first to do it, but - [Interruption.]

Mr Speaker: Order. Let us not have a debate across the Chamber.

Ms Ruane: - today is about the rights of our LGBT communities. You can hide and try to divert the debate, but it will not work with me.

Mr Kennedy did not raise the issue of parades again. Similarly, Members expressed a desire for the issue to be viewed as a matter of conscience, and for viewpoints on the issue not to be 
encouraged by either their party or their position on the constitutional status of the province: "The fact that the House will not split down traditional, defined lines is to be welcomed. There is a variety of views across the Benches, and I hope that will continue to permeate our respective communities" (McKay MLA, Sinn Féin). Although the final vote may have largely been along communal lines, the debate did not have communal politics at its centre.

This is largely reflected in the ensuing debate on the same subject, six months later in April 2013. Again, a petition of concern was filed by the DUP. A motion was tabled by Sinn Féin that expounded similar principles to those seen in the previous October 2012 motion, but framed very differently:

"That this Assembly recognises the importance of the constitutional convention; notes the participation of parties from the Assembly; welcomes the $79 \%$ majority vote at the constitutional convention in favour of marriage equality; and calls on the Executive to bring forward the necessary legislation to allow for same-sex marriage."xiii

Through their evocation of the constitutional convention, a body in the Republic of Ireland, ${ }^{x i v}$ Sinn Féin chose to portray the issue in a way that made it explicitly communal, and of less obvious relevance to Unionists. Unionists were quick to criticise Sinn Féin for their choice in framing the issue of same sex marriage in this manner. Roy Beggs MLA, UUP, declared later in the debate, with reference to the Constitutional Convention that, "Even if I happened to agree with everything else that was said, I would have voted against the motion because of the mere inclusion of the phrase." Similarly, Simon Hamilton MLA, DUP, said that "Why should those of us in Northern Ireland who oppose the redefinition of marriage care what the Irish constitutional convention says on the matter?" This debate carried greater reference to the traditional nationalist-unionist division of Northern Irish politics.

Although, as previously, the debate and ensuing vote largely followed communal lines, with nationalists generally in favour and unionists generally opposed, the thread and logic of the main arguments were not explicitly focused around the constitutional issue. Caitríona Ruane, the Sinn Féin MLA who tabled the amendment, repeatedly attacked opponents of same sex marriage as being against the inevitable progress of equality: "The DUP might block the motion today, but equal marriage is coming. Sinn Féin is proud to stand shoulder to shoulder with the LGBT community. We will play our part in ensuring that change happens, because Sinn Féin is a party of equality". As with the 2012 debate, unionist opponents argued that this was an example of political correctness gone astray, with the definition of equality being stretched too far and thus destroying traditional values: "First, this has been put forward as an issue of equality. It is not an issue of equality. It is an issue of redefining marriage - not marriage as defined by the state, but marriage as it has always been understood" (Wilson MLA, DUP). The debate thus centred along conventional lines of the liberal belief in samesex marriage as an issue of equal treatment before the secular force of the law, and the more conservative argument that any change will attack traditions and vilify those with an opposing viewpoint.

Furthermore, there was cross-party belief that Sinn Féin's position on the issue was paper thin. The party were continually critiqued from all sides of the debate for "grandstanding" an issue and having little thought through policy objectives. The Alliance Party Justice Minister, David Ford, was strongly critical of Sinn Féin's proposal, arguing that it "guarantees some heat, very little light, and absolutely no meeting of minds around the issue", given that it allowed no guarantees for religious freedom. He went on to argue that "It seems to me that 
what we have had today is an attempt by Sinn Féin to create the impression that it is concerned about lesbian and gay equality, but I fear that ... it addresses that party's failure to deliver on things such as a sexual orientation strategy, a single equality Bill, or the issue of homophobic bullying". His comments were echoed by several other MLAs, on both sides of the communal divide (for example, "I believe that those who tabled the motion are guilty of engaging in a cynical political exercise that has no benefit for any section of our community, not least the LGBT community, from which, presumably, Sinn Féin is seeking to garner support." (Kennedy MLA, UUP)), indicating a widespread sentiment across the Assembly that Sinn Féin were not serious in their proposal. Their intentions were questioned, with the proposal allowing the guise of liberal credentials, even if their policy lacked depth.

\section{Discussion}

There is a general tone of strong social conservatism in these debates. On the whole abortion was viewed especially negatively. Even those opposing the amendment to outlaw private terminations were quick to stress that their actions in this debate did not signal their support for more liberal abortion legislation, or for the extension of the 1967 Abortion Act to Northern Ireland. This social conservatism is also reflected in that fact that there was no discussion of the lack of access to abortion women face in Northern Ireland. The debate narrowly focussed only on the specific remit of public versus private provision of services. The reality of abortion as it exists in the province (where hundreds of women are forced to travel to England for terminations every years and pay for them privately (Rossiter, 2009)) was neglected.

This sense of widespread social conservatism cuts across lines of party and political identity. With regards to cross-community action, there appears to be some potential in socio-cultural issues such as these. A jointly proposed motion from the DUP, the UUP and the SDLP, such as the attempted amendment regarding Marie Stopes, is rare, and shows that certain social issues transcend ethno-national division. Indeed, the overarching way in which both issues were discussed (as concerning private or public healthcare, and traditional versus liberal definitions of marriage) was not along communal lines. Instead, these appear as issues that cut across traditional political divisions.

This cross-cutting social conservatism is less apparent in the debates on same sex marriage, when nationalist MLAs appeared largely supportive of marriage equality and unionist MLAs did not. Reflecting previous findings (Lutz and Farrington, 2003, 727), a degree of overlap on this issue appears to occur between the nationalist-unionist and liberal-conservative spectrum. Across both debates on same sex marriage, whilst Sinn Féin promote the issue as fundamental to their vision of equality as a party, the DUP are firmly against any change. Indeed, it is the DUP who present the most staunchly conservative face as far as regards both issues. There appears little space for any liberalisation of views on abortion or same sex marriage from the party in these debates (or in wider consideration of their policy and membership (Tonge et al, 2014, 155)). As the largest party in the Assembly, and with such a strongly socially conservative position, their aversion to any liberal movements on these issues will be difficult to overcome.

The use of the petition of concern to quash all of these debates, by multiple different parties, suggests a desire to avoid the issues. The little literature which has been produced on the petition of concern in Northern Ireland tends to approach it as an instrument which is beneficial to the functioning of the Assembly, and which has not overly dominated proceedings or been misused by parties (Conley and Dahan, 2013, McEvoy, 2013) On the topics of same sex marriage and abortion, however, it has acted to stymie further debate by 

politics?

closing down political conversation. A device which was intended to protect communal interests has been used to restrict movement on social issues. From the limited contemporary data analysed here, there appears to be a danger that this could be increasingly relied upon to avoid decisions on these topics. As such, clear legislative responses to abortion and same-sex marriage are not likely to be forthcoming.

The use of the petition of concern also allows parties to grandstand on issues. Although aware from the previous debate on same sex marriage what the DUP's position on a similar Bill was likely to be, Sinn Féin still proposed a second attempt. As referenced above, Justice Minister David Ford pointed out multiple other ways the party could have chosen to support proLGBT policies and had not done so. By focussing instead on the more visible issue of samesex marriage, even though the Bill was neutralised from the outset via the petition of concern, the party were rewarded with a certain public persona of a perceived liberal stance on LGBT issues.

There is nothing unusual in grandstanding around issues such as these. In many other contexts they have become political footballs, used to score points or emphasise perceived moral differences between party policy: the role of abortion in politics in the USA is a key example here. However, there is a danger that these issues could become exacerbated in a context in which there are already stark social and political differences. The contemporary dominance of Sinn Fein and the DUP looks set to stay. Both parties are keen to highlight differences between them, as DUP members' repeated assertion during the abortion debate that Sinn Féin were an immoral, pro-choice party shows. The DUP appears aware of the potential that stressing this could help to bring the party to certain parts of the Catholic electorate: as Edwin Poots, former Health Minister has said, "there is an educated, conservative Catholic vote out there which the DUP is probably best placed to pick up ... The doctrines of their church largely coincide with the DUP" (quoted in Tonge et al, 2014, 182). Equally, Sinn Féin's stance on same sex marriage has been couched in terms of equality and justice which are key to their identity as a party, and which act to differentiate them from the strongly socially conservative DUP. Socio-cultural issues such as these could be increasingly used to emphasise the difference between two parties which now dominate an institution that neither originally wanted.

\section{Conclusion}

Research on ethno-nationally divided societies has been relatively slow to awaken to issues of gender. For too long seen as an 'extra', or a concern which has little 'real' relevance, gender is now understood as an important factor when analysing post-conflict societies. Yet the ways in which specific gender issues are dealt with in ethno-nationally divided contexts has rarely been considered.

Northern Ireland is no exception to this picture. Consideration of policy-making and politics around particular gender issues has largely been neglected, but has much to tell us about how post-conflict politics are developing. Whilst there is some overlap between abortion and same-sex marriage in the Northern Irish situation, these policy areas are clearly separate in both the public and political mindset. Understanding them as such helps to appreciate how party policy, political attitudes and, in the Northern Irish case outlined here, parliamentary procedure in new political institutions, develop. Indeed, disaggregating between different gender issues helps to build a fuller picture of how they might be "politically consequential" (Htun, 2003, 2), by illustrating the new political relationships that they are encouraging between parties and communities. 

politics?

The broad social conservatism at play in this example warrants further, comparative inquiry. Are societies emerging from conflict and wide-spread violence more likely to be reticent to introduce progressive social legislation? Or is this, in the strongly church-going Northern Irish context, unique to this example? The differentiation between abortion and same-sex marriage also prompts further research: is abortion always the "mother issue"" (Engeli et al, 2012 , 197) on which political figures of different hues find it easiest to agree, and why? Finally, the reliance on the veto mechanism, a feature also present in other post-conflict institutions (McEvoy, 2013) is important: is it being similarly used in other contexts to deflect decision-making on gender issues?

This article has emphasised the ways in which abortion and same sex marriage are political topics. Issues of morality and sexuality are often deemed to be 'merely' social, or peripheral to 'real' political issues, but, are, as Engeli et al argue, "the Achilles heel of the modernisation of Christian Democracy" (Engeli et al, 2012, 198). Furthermore, as illustrated here, they can help to highlight key tensions and unexpected alliances in developing democratic institutions. Gendered issues such as abortion and same-sex marriage are not an 'extra' to the politics of post-conflict settings but, rather, have much to tell us about how politics in these regions is developing. 
Abortion and same-sex marriage: how are non-sectarian controversial issues discussed in Northern Irish politics?

Tables

Table 1: the Northern Ireland Assembly by MLA party affiliation, 1998

\begin{tabular}{|l|l|l|l|l|l|l|l|l|l|}
\hline Party & UUP & SDLP & DUP & $\begin{array}{l}\text { Sinn } \\
\text { Féin }\end{array}$ & Alliance & $\begin{array}{l}\text { UK } \\
\text { Unionist } \\
\text { Party }\end{array}$ & $\begin{array}{l}\text { Independent } \\
\text { Unionist }\end{array}$ & PUP & $\begin{array}{l}\text { NI } \\
\text { Women's } \\
\text { Coalition }\end{array}$ \\
\hline $\begin{array}{l}\text { Number } \\
\text { of } \\
\text { MLAs }\end{array}$ & 28 & 24 & 20 & 18 & 6 & 5 & 3 & 2 & 2 \\
\hline
\end{tabular}

Table 2: the Northern Ireland Assembly by MLA party affiliation, 2015

\begin{tabular}{|l|l|l|l|l|l|l|l|l|l|l|}
\hline Party & DUP & $\begin{array}{l}\text { Sinn } \\
\text { Féin }\end{array}$ & SDLP & UUP & Alliance & NI21 & $\begin{array}{l}\text { Green } \\
\text { (NI) }\end{array}$ & TUV & UKIP & Independent \\
\hline $\begin{array}{l}\text { Number } \\
\text { of } \\
\text { MLAs }\end{array}$ & 38 & 29 & 14 & 13 & 8 & 1 & 1 & 1 & 1 & 2 \\
\hline
\end{tabular}

Table 3: Do you personally think it is wrong or not wrong for a woman to have an abortion if the family has a very low income and cannot afford any more children? $(\%)$

\begin{tabular}{|l|l|l|l|}
\hline & Catholic & Protestant & No religion \\
\hline Always wrong & 53 & 39 & 30 \\
\hline $\begin{array}{l}\text { Almost always } \\
\text { wrong }\end{array}$ & 15 & 20 & 10 \\
\hline $\begin{array}{l}\text { Wrong only } \\
\text { sometimes }\end{array}$ & 13 & 16 & 15 \\
\hline Not wrong at all & 9 & 14 & 31 \\
\hline Can't choose & 11 & 12 & 14 \\
\hline
\end{tabular}

Source: Northern Ireland Life and Times Survey, 2008, n=1215

Table 4: Do you personally think it is wrong or not for a woman to have an abortion if there is a strong chance of a serious defect in the baby? (\%)

\begin{tabular}{|l|l|l|l|}
\hline & Catholic & Protestant & No religion \\
\hline Always wrong & 35 & 21 & 16 \\
\hline $\begin{array}{l}\text { Almost always } \\
\text { wrong }\end{array}$ & 15 & 14 & 10 \\
\hline $\begin{array}{l}\text { Wrong only } \\
\text { sometimes }\end{array}$ & 21 & 24 & 26 \\
\hline Not wrong at all & 16 & 31 & 38 \\
\hline Can't choose & 13 & 11 & 10 \\
\hline
\end{tabular}

Source: Northern Ireland Life and Times Survey, 2008, n=1215

Table 5: Do you think marriages between same-sex couples should or should not be recognised by the law as valid, with the same rights as traditional marriages? (\%) 
Abortion and same-sex marriage: how are non-sectarian controversial issues discussed in Northern Irish politics?

\begin{tabular}{|l|l|l|l|}
\hline Should be valid & 65 & 44 & 73 \\
\hline Should not be valid & 23 & 45 & 22 \\
\hline Don't know & 12 & 11 & 2 \\
\hline
\end{tabular}

Source: Northern Ireland Life and Times Survey, 2012, n=1204

\section{Bibliography}

Ashe, Fidelma, 2008, "Gender and Ethno-nationalist Politics in Northern Ireland" in Colin Coulter and Murray, Michael (ed.s), Northern Ireland After the Troubles, Manchester University Press, pp. 45-60.

- 2009, “Iris Robinson's Excitable Speech: Sexuality and conflict transformation in Northern Ireland", Politics, Volume 29, Issue 1

Assembly and Executive Review Committee, Stormont, "Review of Petitions of Concern", March 2014.

http://www.niassembly.gov.uk/Documents/Reports/Assem_Exec_Review/10170.pdf. Accessed $3^{\text {rd }}$ December 2014.

Bloomer, Fiona and Kellie O'Dowd, 2014, "Restricted access to abortion in the Republic of Ireland and Northern Ireland", Culture, Health and Sexuality, Volume 16, Issue 4

- $\quad$ and Eileen Fegan, 2014, "Critiquing recent abortion law and policy in Northern Ireland", Critical Social Policy, Volume 34, Issue 1

Brewer, John D., Gareth I. Higgins, and Francis Teeney, 2011, Religion, Civil Society, and Peace in Northern Ireland, Oxford University Press, Oxford

Cockburn, Cynthia and Dubravka Zarkov (ed.s), 2002, The Postwar Moment: Militaries, Masculinities, and International Peacekeeping, Zed books, London

Collier, Paul, 2010, Wars, Guns and Votes: Democracy in Dangerous Places, Vintage

Conley and Dahan, 2013, "Legislative Behaviour in the Northern Irish Assembly 2007-2011: Conflict and Consensus in a Developing Consociational Democracy", Political Studies, 61, Issue Supplement S1, pp. 179-197

Cowell-Meyers, Kimberly, 2001, "Gender, Power and Peace: A Preliminary Look at Women in the Northern Ireland Assembly," Women and Politics, Volume 22, Issue 4

Curtis, Jennifer, 2013, "Pride and Prejudice: Gay rights and religious moderation in Belfast", Sociological Review, Volume 61, Issue Suppl. 2.

Duggan, Marian, 2012, Queering Conflict: Examining Lesbian and Gay Experience of Homophobia in Northern Ireland, Ashgate

Engeli, Isabelle, Cristoffer Green-Pedersen and Lars Thorup Larsen (ed.s), 2012, Morality Politics in Western Europe: Parties, Agendas and Policy Choices, Palgrave Macmillan

Enloe, Cnythia, 1993, The Morning After: Sexual Politics at the End of the Cold War, University of California Press 
Abortion and same-sex marriage: how are non-sectarian controversial issues discussed in Northern Irish politics?

Evans, J.A.J., and J. Tonge, 2009, "Social class and party choice in Northern Ireland's ethnic blocs", West European Politics Volume 32, no. 5, pp.1012-1030.

Fearon, Kate, 1999. Women's Work: the Story of the Northern Ireland Women's Coalition. Belfast: Blackstaff Press.

Fegan, Eileen V. and Rachel Rebouche, 2003, "Northern Ireland's Abortion Law: The Morality of Silence and the Censure of Agency”, Feminist Legal Studies, Volume 11, No.3

Galligan, Yvonne, Eilís Ward and Rick Wilford (eds.), 1999. Contesting Politics: Women in Ireland, North and South. Boulder, Colorado: Westview Press and PSAI Press.

Harrington, Carol, 2010, Politicization of sexual violence: from abolitionism to peacekeeping, Ashgate

Horgan, Goretti and Julia S. O’Connor, 2014, “Abortion and Citizenship Rights in a Devolved Region of the UK”, Social Policy and Society, Volume 13

Htun, Mala, 2003, Sex and the State: Abortion, Divorce and the Family Under Latin American Dictatorships and Democracies, Cambridge University Press

Larsen, Lars Thorup, Donley T. Studlar and Cristoffer Green-Pedersen, 2012, "Morality Politics in the United Kingdom: Trapped between Left and Right" in Morality Politics in Western Europe: Parties, Agendas and Policy Choices, Palgrave Macmillan

Lutz, Karin, and Christopher Farrington, 2006, "Alternative Ulster? Political parties and the Non-constitutional Policy Space in Northern Ireland”, Political Studies, Vol. 54, Issue 4, pp. $715-742$

Matthews, Neil, 2014, "Gendered candidate selection and the representation of women in Northern Ireland”, Parliamentary Affairs, Volume 67, Issue 3

McEvoy, Joanne, 2013, "We Forbid! The Mutual Veto and power-sharing democracy" in Joanne McEvoy and Brendan O'Leary (ed.s) Power Sharing in Deeply Divided Places, University of Pennsylvania Press

Mcleod, Laura, 2011, "Configurations of Post-conflict: Impacts of representations of conflict and post-conflict upon the (political) translations of gender security within UNSCR 1325", International Feminist Journal of Politics Volume 13, Issue 4.

Mitchell, P., G. Evans, and B. O’Leary, 2009, "Extremist outbidding in ethnic party systems is not inevitable: Tribune parties in Northern Ireland", Political Studies, Volume 57, no. 2, pp. 397-421.

Moser, Caroline and Fiona Clark, 2001, Victims, Perpetrators or Actors: Gender, Armed Conflict and Political Violence, Zed Books: London

Mycock and McDaid, 2014, "Stem the tide of Northern Ireland's 'culture wars", https://www.opendemocracy.net/andrew-mycock-shaun-mcdaid/stem-tide-of-northernireland\%E2\%80\%99s-\%E2\%80\%98culture-wars\%E2\%80\%99. Accessed 24/02/15. 
Abortion and same-sex marriage: how are non-sectarian controversial issues discussed in Northern Irish politics?

Nagle, John, 2013, “'Unity in Diversity': Non-sectarian Social Movement Challenges to the Politics of Ethnic Antagonism in Violently Divided Cities”, International Journal of Urban and Regional Research, Volume 37, Issue 1

Northern Ireland Life and Times Survey, http://www.ark.ac.uk/nilt/. Accessed $16^{\text {th }}$ May, 2014.

O'Keefe, Theresa, 2013, Feminist Identity Development and Activism in Revolutionary Movements, Palgrave Macmillan

O'Leary, Brendan, 2004, “The Nature of the Agreement”, McGarry, John and Brendan O'Leary, The Northern Ireland Conflict: Consociational Engagements, Oxford University Press

Parker, Andrew, Mary Russo, Doris Summer and Patricia Yaeger, 1992, Nationalisms and Sexualities, New York: Routledge

Rossiter, Ann, 2009, Ireland's Hidden Diaspora: the 'abortion trail' and the making of a London-Irish underground, 1980-2000, IASC Publishing

Sheldon, Sally, 1997, Beyond Control: Medical Power and Abortion Law, Pluto Press, London

Shepherd, Laura, 2008, Gender, Violence and Security: Discourse as Practice, Zed Books, London

Sinn Féin, 2004a, Women in an Ireland of Equals, Sinn Féin

Sinn Féin, 2004b, Rights for All, Sinn Féin

Smyth, Lynda, 2006, "The Cultural Politics of Sexuality and Reproduction in Northern Ireland", Sociology, Volume 40, Issue 4

Stormont House Agreement, December 2014.

https://www.gov.uk/government/uploads/system/uploads/attachment_data/file/390672/Storm ont_House_Agreement.pdf. Accessed 04/01/15.

Tilley, J., and G. Evans., 2011, "Political generations in Northern Ireland”, European Journal of Political Research, Volume 50, no. 5, pp. 583-608.

Tonge, Jonathan, 2005, The New Northern Irish Politics? Palgrave, London

Tonge, Jonathan, Maire Braniff, Thomas Hennessy, James W. McAuley and Sophie Whiting, 2014, The Democratic Unionist Party: From protest to power, OUP

Ward, Rachel, 2002. "Invisible Women: The Political Roles of Unionist and Loyalist Women in Contemporary Northern Ireland", Parliamentary Affairs, Volume 55, Issue 1, pp.167-78.

\footnotetext{
i Green and Orange are used to refer to Irish (republican) and British (unionist) nationalisms respectively in Northern Ireland.
} 
Abortion and same-sex marriage: how are non-sectarian controversial issues discussed in Northern Irish politics?

\footnotetext{
ii http://www.bbc.co.uk/news/uk-northern-ireland-24458241. Accessed 27/02/15.

iii http://www.belfasttelegraph.co.uk/news/northern-ireland/dups-jim-wells-abortion-should-be-ruled-out-forrape-victims-28785234.html. Accessed 20/03/15.
}

iv http://web.archive.org/web/20071025033401/http://www.sinnfein.ie/news/detail/21360. Accessed 17/02/15.

${ }^{v}$ All MLAs must designate as either Nationalist, Unionist or Other. No Member may change their selfdesignated category more than once in an Assembly session.

${ }^{\text {vi }}$ With a slightly different legal precedent in Scotland.

vii http://www.theguardian.com/society/2008/oct/21/health-health1?guni=Article:in\%20body\%20link. Accessed $11 / 05 / 15$.

viii Answers have varied only within five percentage points, and abortion for social as opposed to medical reasons has always been given a lower rate of approval.

ix The opinions of several politicians interviewed as part of a larger project on the part of the author, are similar.

${ }^{\mathrm{x}}$ http://www.bbc.co.uk/news/uk-northern-ireland-21755507. Accessed 11/05/15.

xi Official Report, Hansard, Stormont, Tuesday 12 ${ }^{\text {th }}$ March, 2013, Volume 83, No. 2.

http://www.niassembly.gov.uk/Assembly-Business/Official-Report/Reports-12-13/12-March-2013/. Accessed $11 / 05 / 15$. All further references to this debate are from this source.

xii Official Report, Hansard, Stormont, Monday $1^{\text {st }}$ October 2012, Volume 77, No. 7. http://www.niassembly.gov.uk/Documents/Official-Reports/Plenary/2012-13/Plenary-01-10-12.pdf. Accessed $11 / 05 / 15$. All further references to this debate are from this source.

xiii Official Report, Hansard, Stormont, Monday $29^{\text {th }}$ April 2013, Volume 84, No. 5. http://www.niassembly.gov.uk/Assembly-Business/Official-Report/Reports-12-13/29-April-2013/. Accessed $11 / 05 / 15$. All further references to this debate are from this source.

xiv "The Convention on the Constitution is a forum of 100 people, representative of Irish society and parliamentarians from the island of Ireland, with an independent Chairman. The Convention was established by Resolution of both Houses of the Oireachtas to consider and make recommendations on certain topics as possible future amendments to the Constitution." https://www.constitution.ie/Convention.aspx. Accessed 11/05/15. 